\title{
A Systematic Review about Educational Interventions aimed to prevent Hookah Smoking
}

\author{
Review Article
}

\section{Reza Sadeghi ${ }^{1}$, Seyed Saeed Mazloomy Mahmoodabad ${ }^{2 *}$. Hossein Fallahzadeh ${ }^{3}$, Mohsen Rezaeian ${ }^{4}$, Reza Bidaki $^{5}$, Narges Khanjani ${ }^{6}$}

1. PhD Candidate, Social Determinants of Health Research Center, Department of Health Education \& Promotion,

School of Public Health, Shahid Sadoughi University of Medical Sciences, Yazd, Iran.

2. Professor, Social Determinants of Health Research Center, Department of Health Education \& Promotion,

School of Public Health, Shahid Sadoughi University of Medical Sciences, Yazd, Iran

3. Professor, Research Center of Prevention and Epidemiology of Non-Communicable Disease,

Departments of Biostatistics and Epidemiology, School of Public Health,

Shahid Sadoughi University of Medical Sciences, Yazd, Iran.

4. Professor, Epidemiology and Biostatistics Department, Occupational Environmental Research Center,

Rafsanjan Medical School, Rafsanjan University of Medical Sciences, Rafsanjan, Iran.

5. Associate Professor, Research Center of Addiction and Behavioral Sciences, Diabetes Research Center,

Shahid Sadoughi University of Medical Sciences, Yazd, Iran

6. Associate Professor, Neurology Research Center, Kerman University of Medical Sciences, Kerman, Iran.

\begin{abstract}
Background: Smoking hookahs is one of the most preventable risk factors of Non-Communicable diseases. It is also considered a gateway to addiction. This systematic review was conducted to summarize the effect of educational interventions on the prevention and control of hookah consumption. Methods: Eight databases including PubMed, Web of Science, Google Scholar, Embase, Scopus, IranMedex, SID and Magiran were searched from January 2008 to December 2018. The inclusion criteria were experimental or semi-experimental educational interventions designed to prevent hookah smoking. Results: The initial search ended up with 1610 articles. Finally, 12 articles were included. The intervention durations were from 1 to 9 months. The main groups under investigation were young people and adolescence. In the included studies, the predominant educational model was KAP (4studies), and then TPB ( 2 studies). Eleven of the educational interventions showed a positive effect for education on preventing and controlling hookah use. Conclusion: Targeted health education interventions are effective in preventing and controlling hookah use; and proper planning and implementation can increase the effectiveness of health services and programs. It is recommended that future studies extend the length of follow-up and use modern training methods, and in multiple settings.
\end{abstract}

Keywords: Hookah, Health, Educational Intervention, Systematic Review.

\section{Introduction}

Hookah smoking is now considered a global epidemic. Hookah has become popular in many parts of the world and is a public health crisis (1). Smoking hookahs is one of the most preventable risk factors for Non-Communicable diseases and it is also considered as the gateway to youth addiction (2).

Hookah is also known as shisha, narghile, waterpipe, gouza, hubble-bubble and ghalyan (3). Similar to smoking cigarettes, hookah smoke contains nicotine, tar, carbon monoxide and heavy metals (4). It

*Corresponding Author:

Seyed Saeed Mazloomy Mahmoodabad,

Professor, Social Determinants of Health Research Center, Department of Health Education \& Promotion, School of Public Health, Shahid Sadoughi University of Medical Sciences, Yazd, Iran

Email id: mazloomy@ssu.ac.ir can increase the risk of coronary heart disease, lung cancer, oral and bladder cancers, and decrease pulmonary function. These adverse effects may affect exposed nonsmokers as well (3). Using shared oral tubes is a common custom among hookah smokers, and can cause disease transmission (2). Repeated hookah smoking may lead to nicotine dependency (5).

Daily about 100 million people in the world consume hookah and statistics show a high rate of hookah consumption, especially among adolescents and young people (6). The results of studies show that the prevalence of hookah smoking among youths across the world ranges from 5.3 to $63 \%$ (7-9). These results show many young people try smoking hookah and may develop addiction or dependency (10). Young people are the active and productive group of each society, and have a prominent role in the future of each country. But, smoking hookah among the youth can lead to drug addiction and disease (11). 
Several factors are involved in the increased rates of smoking hookah. The most important reasons for its use from the public's point of view is people's lack of knowledge about its harms, the availability of various tobacco flavors, its low costs, social acceptance, youths attempt to gain personal and social identity, enjoyment and self-esteem (12). From the World Health Organization's point of view, misconceptions about the safe and harmless nature of hookah is the main reason for its consumption (13).

Planning and training to prevent this health problem is an important health priority. One of the effective ways to change behavior is health education and educational interventions (14). An intervention is a combination of programs or strategies designed to produce behavior changes or prevent, improve, and stabilize a health status among individuals or an entire population (15). Interventions may be implemented in different settings including communities, worksites, schools, health care organizations, faith-based organizations or in the home. Interventions implemented in multiple settings and using multiple strategies may be the most effective because of their potential to reach a larger number of people in a variety of ways (16). Educational interventions for risky behaviors, include programs aimed at reducing or preventing high-risk behaviors such as hookah use (17).

So far, there has not been a systematic review about the impact of educational interventions on hookah consumption. Therefore, this systematic review was conducted about educational interventions aimed at preventing or controlling hookah consumption.

\section{Materials and Methods \\ Search strategies}

Searches were done on December 23, 2018 in the following electronic databases; Google Scholar, Embase, Scopus, PubMed, Web of Science, for Latin articles, and Magiran, SID, and IranMedex for Persian articles.

Searches were carried out from January 2008 to December 2018; because before 2008, hookah consumption was not so common, and there were few studies that met the inclusion criteria. The search was conducted using the keywords shown in table 1 .

Table 1. Search strategy in this systematic review

\begin{tabular}{|l|l|}
\hline 1 & $\begin{array}{l}\text { Health education OR Educational intervention } \\
\text { OR Effect }\end{array}$ \\
\hline 2 & $\begin{array}{l}\text { "Waterpipe", "Hookah","Goza", "Shisha", } \\
\text { "Narghile", "Smoking" }\end{array}$ \\
\hline 3 & 1 AND 2 \\
\hline
\end{tabular}

\section{Inclusion and Exclusion Criteria}

Inclusion criteria included: 1- Quantitative studies, 2Original research, 3- Interventional studies, 4- Interventions that aimed to control hookah consumption, alone and not with any other health hazard. Exclusion Criteria included: review studies, and non-interventional studies.

\section{Quality Assessment}

The Consolidated Standards of Reporting Trials (CONSORT) were used for reporting standard studies. This checklist contains 25 questions, which each question is given a 0 or 1 score. Studies that scored more than 15 were included and studies with a score of 15 or below were excluded. (18).

\section{Extracting data}

Articles were checked according to methodology, and some articles were excluded. Two referees independently reviewed the criteria for including studies, and in case of disagreement between the authors, the third referee was used.

The information extracted from the articles were summarized in tables. The information extracted included the target population, the type of intervention, and the results of educational interventions. The study information was extracted according to a standard form. This form included the names of the authors, the location of the study, the year of study, the purpose of the study, the type of study, the target group, the population size, the description of the intervention, and the most important results of the selected articles (Table 2).

\section{Results}

After searching the aforementioned electronic databases, 1610 related articles (964 in English and 646 in Persian) were retrieved. A large number of articles (1201 articles) were duplicates and were deleted. From the remaining 409 articles, 391 were excluded because they were reviews, or non-interventional studies. Six studies were excluded because they aimed to prevent both cigarettes and hookahs. Finally, 12 studies (6 English papers and 6 Persian articles) entered the review (Figure 1).

\section{Figure 1: Flowchart for selection of studies}

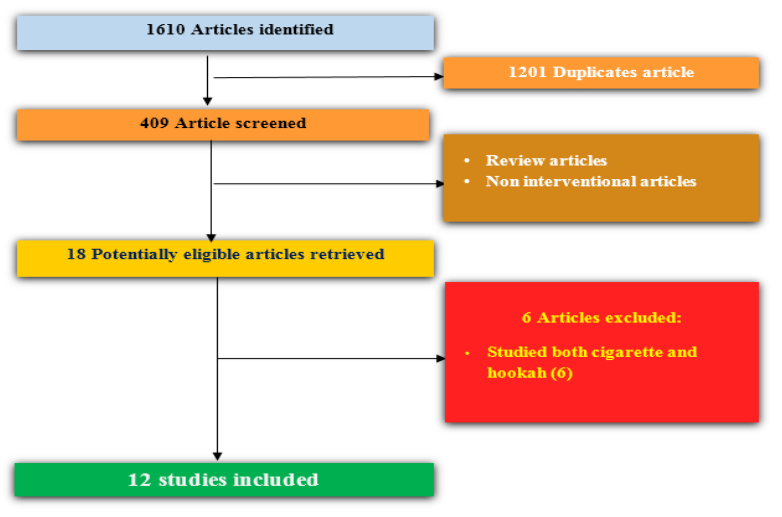

The information from the selected studies, including the name of the first author, the year of publication, the place of the study, the target group, the sample size, the purpose of the study, the educational theory / model, the variables studied, the intervention and its duration, and the results of the intervention and the CONSORT score are summarized in table 2 . 
Table 2. Summary of articles included in this review

\begin{tabular}{|c|c|c|}
\hline \multirow[t]{7}{*}{ Islam, 2016 (19) } & $\begin{array}{l}\text { Place/ Study } \\
\text { population }\end{array}$ & South Carolina, USA/ students \\
\hline & Size of the sample & 367 (without control group) \\
\hline & $\begin{array}{l}\text { Model/ Theory or } \\
\text { construct }\end{array}$ & KAP \\
\hline & Study variables & Attitudes, water pipe use \\
\hline & $\begin{array}{l}\text { Intervention } \\
\text { method/ Duration } \\
\text { of intervention }\end{array}$ & Pictorial health warning labels / 1 month \\
\hline & Results & $\begin{array}{l}\text { Pictorial labels warning about harm to children were the most effective in } \\
\text { motivating water pipe smokers to think about quitting }(\mathrm{p}<0.05) \text {. }\end{array}$ \\
\hline & CONSORT score & 17 \\
\hline \multirow[t]{7}{*}{ Leavens, 2014 (20) } & $\begin{array}{l}\text { Place/ Study } \\
\text { population }\end{array}$ & Midwest, USA/ $\geq 18$ years old \\
\hline & Size of the sample & 109 (Intervention: $\mathrm{n}=53$; Control: $\mathrm{n}=55$ ) \\
\hline & $\begin{array}{l}\text { Model/ Theory or } \\
\text { construct }\end{array}$ & KAP \\
\hline & Study variables & Knowledge, Perceived Harmfulness, water pipe smoking \\
\hline & $\begin{array}{l}\text { Intervention } \\
\text { method/ Duration } \\
\text { of intervention }\end{array}$ & $\begin{array}{l}\text { The intervention group received health risk information about water pipe } \\
\text { in } 2 \text { sessions/ } 3 \text { month }\end{array}$ \\
\hline & Results & $\begin{array}{l}\text { In the intervention group knowledge about water pipe-related harms } \\
\text { increased ( } \mathrm{p}<0.0001) \text {, risk perceptions improved }(\mathrm{p}=0.0047) \text {, the } \\
\text { importance of quitting water pipe smoking increased, and participants' } \\
\text { confidence in ability to quit water pipe smoking increased after the } \\
\text { intervention ( } \mathrm{p}=0.0132 \text { ). But, no significant difference }(\mathrm{p}>0.05) \text { was } \\
\text { observed in water pipe smoking after } 3 \text { months follow-up between the } \\
\text { intervention and control group. }\end{array}$ \\
\hline & CONSORT score & 20 \\
\hline \multirow[t]{7}{*}{ Ezati, 2015 (21) } & $\begin{array}{l}\text { Place/ Study } \\
\text { population }\end{array}$ & BandarAbbas, Iran/ women aged above 15 \\
\hline & Size of the sample & 128(Intervention: $\mathrm{n}=64 ;$ Control: $\mathrm{n}=64)$ \\
\hline & $\begin{array}{l}\text { Model/ Theory or } \\
\text { construct }\end{array}$ & TPB \\
\hline & Study variables & $\begin{array}{l}\text { attitude, behavior intention, subjective norms and perceived behavior } \\
\text { control }\end{array}$ \\
\hline & $\begin{array}{l}\text { Intervention } \\
\text { method/ Duration } \\
\text { of intervention }\end{array}$ & $\begin{array}{l}4 \text { sessions each taking } 60-90 \text { minutes as lecture, group discussion, } \\
\text { question and answers, role play and handing out a guide book./ } 2 \text { months }\end{array}$ \\
\hline & Results & $\begin{array}{l}\text { Results revealed a significant increase in the mean scores of the following } \\
\text { variables: attitude }(p<0.0001) \text {, behavior intention }(p<0.0001) \text {, subjective } \\
\text { norms }(p<0.0001) \text {, and perceived behavior control }(p<0.0001) \text {. Water pipe } \\
\text { smoking among the participants significantly decreased }(p<0.0001) \text { in the } \\
\text { intervention group. }\end{array}$ \\
\hline & CONSORT score & 19 \\
\hline \multirow[t]{5}{*}{$\begin{array}{l}\text { Momenabadi, } 2014 \\
\text { (22) }\end{array}$} & $\begin{array}{l}\text { Place/ Study } \\
\text { population }\end{array}$ & Kerman, Iran/ university students \\
\hline & Size of the sample & 80 (Intervention: $\mathrm{n}=40 ;$ Control: $\mathrm{n}=40$ ) \\
\hline & $\begin{array}{l}\text { Model/ Theory or } \\
\text { construct }\end{array}$ & BASNEF \\
\hline & Study variables & attitude, subjective norms, and behavioral intention \\
\hline & $\begin{array}{l}\text { Intervention } \\
\text { method/ Duration } \\
\text { of intervention }\end{array}$ & $\begin{array}{l}\text { two } 30 \text {-min educational meetings (group discussion, question and answer) } \\
\text { were performed. Researchers also provided a CD containing images of } \\
\text { tobacco-induced cancer cases, warning posters in intervention } \\
\text { dormitories, and educational pamphlets/ } 2 \text { months }\end{array}$ \\
\hline
\end{tabular}


International Journal of Ayurvedic Medicine, 2019, 10(1), 14-21

\begin{tabular}{|c|c|c|}
\hline & Results & $\begin{array}{l}\text { The intervention decreased water pipe smoking among university } \\
\text { students }(p=0.0001) \text {; and the educational intervention positively } \\
\text { influenced individuals' attitude }(p=0.0001) \text {, subjective norms }(p= \\
0.0001) \text {, and behavioral intention ( } p=0.0001) \text {, but no significant } \\
\text { difference }(p>0.05) \text { was observed in enabling factors }(p=0.323) \text {. }\end{array}$ \\
\hline & CONSORT score & 18 \\
\hline Anjum, 2008 (23) & $\begin{array}{ll}\text { Place/ } & \text { Study } \\
\text { population }\end{array}$ & Karachi, Pakistan \\
\hline & Size of the sample & 646(without control group) \\
\hline & $\begin{array}{l}\text { Model/ Theory or } \\
\text { construct }\end{array}$ & KAP \\
\hline & Study variables & knowledge, attitude and practices \\
\hline & $\begin{array}{l}\text { Intervention } \\
\text { method/ Duration } \\
\text { of intervention }\end{array}$ & Eight interactive health sessions/ 2 months \\
\hline & Results & $\begin{array}{l}\text { Knowledge }(p<0.0001) \text {, health perception }(p<0.0001) \text { and social } \\
\text { perception }(p<0.0001) \text { significantly increased after the intervention, } \\
\text { but no significant difference was observed in Shisha smoking after the } \\
\text { educational intervention }(p>0.05) \text {. }\end{array}$ \\
\hline & CONSORT score & 18 \\
\hline Lipkus, 2011 (24) & $\begin{array}{ll}\text { Place/ } & \text { Study } \\
\text { population }\end{array}$ & North Carolina, USA/ university students \\
\hline & Size of the sample & 203(Intervention: $\mathrm{n}=91$; Control: $\mathrm{n}=112$ ) \\
\hline & $\begin{array}{l}\text { Model/ Theory or } \\
\text { construct }\end{array}$ & KAP \\
\hline & Study variables & $\begin{array}{l}\text { perceived risks, Perceived personal risk of harm, Perceived knowledge } \\
\text { of harms }\end{array}$ \\
\hline & $\begin{array}{l}\text { Intervention } \\
\text { method/ Duration } \\
\text { of intervention }\end{array}$ & $\begin{array}{l}\text { Two web-based studies were conducted and college water pipe users } \\
\text { received information about the spread of and use of flavored tobacco in } \\
\text { water pipe and the harms of water pipe smoking / } 6 \text { month }\end{array}$ \\
\hline & Results & $\begin{array}{l}\text { After pooling data from both studies, participants who received } \\
\text { information about the harms of water pipe smoking reported a greater } \\
\text { perceived risk }(p=0.009) \text { and more worry about harm and addiction } \\
(p=0.0063) \text { and expressed a stronger desire to quit }(p=0.028) \text {. In Study } \\
1,62 \% \text { of participants in the experimental group versus } 33 \% \text { in the } \\
\text { control group reported having stopped water pipe use }(p<0.05) \text {. }\end{array}$ \\
\hline & CONSORT score & 19 \\
\hline Fathi, 2016 (25) & $\begin{array}{l}\text { Place/ Study } \\
\text { population }\end{array}$ & Lorestan, Iran/ post-secondary students \\
\hline & Size of the sample & 126(Intervention: $\mathrm{n}=63$; Control: $\mathrm{n}=63$ ) \\
\hline & $\begin{array}{l}\text { Model/ Theory or } \\
\text { construct }\end{array}$ & ТPB \\
\hline & Study variables & attitude, subjective norms and behavioral intention \\
\hline & $\begin{array}{l}\text { Intervention } \\
\text { method/ Duration } \\
\text { of intervention }\end{array}$ & $\begin{array}{l}\text { The intervention comprised of four sessions including, Lecture, focus } \\
\text { group discussion, brain storming, and, problem solving training/3 } \\
\text { months }\end{array}$ \\
\hline & Results & $\begin{array}{l}\text { Significant differences were observed in average scores of attitude } \\
(\mathrm{p}<0.001) \text {, subjective norms }(\mathrm{p}<0.001) \text { and behavioral intention } \\
(\mathrm{p}<0.001) \text {, between the experimental and control groups, in favor of } \\
\text { the experimental group. Results also showed that there was a } \\
\text { significant difference in hookah smoking rates after the intervention } \\
(\mathrm{p}=0.007) \text { and rates were less in the intervention group. }\end{array}$ \\
\hline & CONSORT score & 22 \\
\hline
\end{tabular}




\begin{tabular}{|c|c|c|}
\hline \multirow[t]{7}{*}{$\begin{array}{l}\text { Rajabalipour,2016 } \\
\text { (26) }\end{array}$} & $\begin{array}{l}\text { Place/ Study } \\
\text { population }\end{array}$ & Kerman, Iran/ adolescents \\
\hline & Size of the sample & 189(Intervention: $\mathrm{n}=94 ;$ Control: $\mathrm{n}=95$ ) \\
\hline & $\begin{array}{l}\text { Model/ Theory or } \\
\text { construct }\end{array}$ & $\mathrm{SCT}$ \\
\hline & Study variables & knowledge, outcome expectations, environmental influences \\
\hline & $\begin{array}{l}\text { Intervention } \\
\text { method/ Duration } \\
\text { of intervention }\end{array}$ & $\begin{array}{l}3 \text { sessions each taking } 30-40 \text { minutes as focus group discussion, lecture, } \\
\text { question and answers/ } 4 \text { month }\end{array}$ \\
\hline & Results & $\begin{array}{l}\text { the results did not show any statistical significance in the rate of water } \\
\text { pipe smoking }(p=0.241) \text {. Significant differences were observed in } \\
\text { average scores of knowledge }(p<0.001) \text {; but self-efficacy }(p=0.21) \text {, } \\
\text { outcome expectations }(p=0.09) \text {, and environmental influences }(p=0.06) \text {, } \\
\text { did not show any statistically significance. }\end{array}$ \\
\hline & CONSORT score & $\begin{array}{ll} & 18\end{array}$ \\
\hline \multirow[t]{7}{*}{ Dawood, 2018 (27) } & $\begin{array}{l}\text { Place/ Study } \\
\text { population }\end{array}$ & Baghdad, Iraq/High Schools students \\
\hline & Size of the sample & 132 (Intervention: $\mathrm{n}=66 ;$ Control: $\mathrm{n}=66)$ \\
\hline & $\begin{array}{l}\text { Model/ Theory or } \\
\text { construct }\end{array}$ & Health Education Program \\
\hline & Study variables & perception, attitude \\
\hline & $\begin{array}{l}\text { Intervention } \\
\text { method/ Duration } \\
\text { of intervention }\end{array}$ & $\begin{array}{l}2 \text { sessions each taking } 30-40 \text { minutes as focus group discussion, and } \\
\text { lecture/ } 3 \text { months }\end{array}$ \\
\hline & Results & $\begin{array}{l}\text { There was a significant difference in the mean score of hookah smoking } \\
\text { perception in the intervention group between pre-and post intervention } \\
(p<0.001) \text {. There was a statistically significant improvement in the mean } \\
\text { score of views about illness due to hookah smoking in intervention } \\
\text { group }(p<0.0001) \text {. }\end{array}$ \\
\hline & CONSORT score & $\begin{array}{lllllll} & 17\end{array}$ \\
\hline \multirow[t]{7}{*}{ Setoudeh, 2016 (28) } & $\begin{array}{l}\text { Place/ Study } \\
\text { population }\end{array}$ & Bushehr, Iran/ women \\
\hline & Size of the sample & 127(Intervention: $\mathrm{n}=63$; Control: $\mathrm{n}=64)$ \\
\hline & $\begin{array}{l}\text { Model/ Theory or } \\
\text { construct }\end{array}$ & HBM \\
\hline & Study variables & HBM constructs and knowledge \\
\hline & $\begin{array}{l}\text { Intervention } \\
\text { method/ Duration } \\
\text { of intervention }\end{array}$ & two sessions of education/ 3 month \\
\hline & Results & $\begin{array}{l}\text { The mean scores of Health Belief Model constructs }(\mathrm{p}<0.001) \text {, and } \\
\text { knowledge }(\mathrm{p}<0.001) \text {, significantly increased in the intervention group, } \\
\text { and nicotine dependence significantly decreased }(\mathrm{p}=0.007) \text {. }\end{array}$ \\
\hline & CONSORT score & $\begin{array}{lll}+21 & 21\end{array}$ \\
\hline \multirow[t]{5}{*}{ Mojahed, 2017 (29) } & $\begin{array}{ll}\text { Place/ Study } \\
\text { population }\end{array}$ & Zahedan, Iran/ pregnant women \\
\hline & Size of the sample & 140(Intervention: $\mathrm{n}=70$; Control: $\mathrm{n}=70$ ) \\
\hline & $\begin{array}{l}\text { Model/ Theory or } \\
\text { construct }\end{array}$ & motivational interviewing (MI) \\
\hline & Study variables & self-efficacy \\
\hline & $\begin{array}{l}\text { Intervention } \\
\text { method/ Duration } \\
\text { of intervention }\end{array}$ & $\begin{array}{l}4 \text { sessions each taking } 60-90 \text { minutes based on motivational } \\
\text { interviewing/ } 2 \text { months }\end{array}$ \\
\hline
\end{tabular}




\begin{tabular}{|c|c|c|}
\hline & Results & $\begin{array}{l}\text { The demographic characteristics and gestational age of women were } \\
\text { comparable between the two groups, but the duration of hookah } \\
\text { consumption in the intervention was more than the control }(\mathrm{P}=0.008) \text {. } \\
\text { While the mean score of self-efficacy of two groups was similar in pre- } \\
\text { intervention, after the intervention, the score of self-efficacy in the } \\
\text { intervention }(60.85 \pm 7.25) \text { was higher than the control group } \\
(22.77 \pm 3.79)(\mathrm{P}<0.001) \text {. }\end{array}$ \\
\hline & CONSORT score & 20 \\
\hline \multirow[t]{7}{*}{ Jawad, 2014 (30) } & $\begin{array}{l}\text { Place/ Study } \\
\text { population }\end{array}$ & London, UK/local government \\
\hline & Size of the sample & 214 (without control group) \\
\hline & $\begin{array}{l}\text { Model/ Theory or } \\
\text { construct }\end{array}$ & communication model \\
\hline & Study variables & awareness. \\
\hline & $\begin{array}{l}\text { Intervention } \\
\text { method/ Duration } \\
\text { of intervention }\end{array}$ & $\begin{array}{l}\text { Intervention was done by using social media (Facebook, Twitter, and } \\
\text { YouTube) and a campaign website/ } 9 \text { months }\end{array}$ \\
\hline & Results & $\begin{array}{l}\text { Facebook attracted campaign supporters but YouTube attracted } \\
\text { opposers. Twitter enabled the most organization-based contact, but } \\
\text { Facebook was the most interactive medium. Facebook users were more } \\
\text { likely to "like" weekday than weekend statuses and more likely to } \\
\text { comment on "shisha fact" than "current affairs" statuses. Follower } \\
\text { subscription increased as our posting rate increased. YouTube video } \\
\text { gained 19,428 views (from all world continents) and } 218 \text { comments } \\
\text { ( } 86 \% \text { from pro-water pipe smokers). }\end{array}$ \\
\hline & CONSORT score & 17 \\
\hline
\end{tabular}

\section{Discussion}

Hookah consumption has become routine in many societies, therefore it is necessary to plan and support educational interventions for stopping its use. The interventions in studies included in this review were training, motivation and support to control hookah smoking (31). Among the studies used in this review, a number of them had no theory or model approach. Health education can be made more effective by using theories or health education models. These models try to modify or reduce existing harmful behaviors and replace them with new behaviors (32). Theoretically-based interventional programs have facilitated change in behaviors by improving the perceptions of the behavioral change process, and the individual and environmental characteristics affecting behavior (14).

In this systematic review, 12 studies in which educational interventions were conducted to prevent or control hookah use, were included. In these studies, the most popular population under study were adolescents, young people and students. This age group is the most vulnerable to hookah smoking, because of the impact of the environment and peers.

Although numerous studies have proven the harmful effects of hookah smoking; there is a misconception, that hookah smoking is safer or less dangerous compared to cigarette smoking (33). A study done among university students in Jordan mentioned that the majority of the youth, as well as their parents, were not aware of the dangers of hookah smoking (34). Tee et al. reported that young people from many countries do not have enough knowledge about hookah and its hazards (35).

In this study, a large number of educational interventions were excluded due to the lack of appropriate criteria because they were reviews studies, noninterventional studies, or aimed to prevent both cigarettes and hookahs. In the included studies, the predominant model was KAP, which was used in four articles. After intervention, there was a significant change in knowledge, attitude and behavior in most studies; and in most people, information about the harms of hookah smoking increased, and people found negative attitudes about hookah consumption and quitted it.

In two of the included studies, the theory of planned behavior was used. In these studies, the structures of attitude, subjective norms, intent and perceived behavioral control were examined. In these studies, significant changes were made in the scores of the structures; and the amount of hookah consumption decreased significantly in the intervention group $(21,25)$. One study was conducted with the BASNEF model. The results of this study indicated that the scores of the constructs of this model (attitude, subjective norms and behavioral intention) increased and the amount of hookah consumption decreased (22). One study was also conducted based on social cognitive theory, but only knowledge increased after the intervention; and selfefficacy, expectations and environmental influence did not changed significantly, and no change was seen in hookah 
consumption (36). Some possible reasons for this lack of effect was the inadequacy of educational materials, or the inappropriateness of educational materials for the target group.

Jawad et al conducted a study, by a social media campaign (using Facebook, Twitter, and YouTube) about hookah harms, and showed that this campaign was effective in propagating hookah-related facts in London using social media (30). Other studies conducted with the Health Belief Model, Motivational Interview and Health Education Program indicate an increase in the average scores of the structures and a decrease in hookah consumption.

The duration of the intervention in these studies varied from one month to 9 months, the longest intervention period belonged to the social media campaign and was about the dangers of hookah smoking (30). Studies show that the efficacy of studies that had longer interventions and used combined interventions was more than single-dimensional interventions (37).

In most studies, lecture, question and answer training, focused group discussion, pamphlets, and CDs, were used. Social media were used in only one social media campaign. While new training has focused on community-based education, the combination of these traditional methods along with new methods can improve the quality and effectiveness of education (38). In health promotion, there is a need for health innovation, and combined interventions (including community-based methods such as peer education, increase access, education based on the cultural characteristics of the target community, key people, using networking, etc.), can lead to better results (36).

The settings of training sessions, is also very influential and important (39). The settings include schools / universities, workplaces, health centers and the community (32). In the studies included in this review, the most popular settings was the university or schools (19, 22 ), and health centers (28), but other settings such as workplaces, and the community was not used. A multilevel settings can be more influential in a variety of community-based approaches.

In most studies, the immediate effect of the educational intervention was evaluated and there was no follow up. It is possible that after some time, the change in behavior created by the intervention fades away. Therefore, we recommend that the outcomes be investigated after longer follow-ups.

\section{Conclusion}

Targeted health education and health promotion interventions are effective in preventing and controlling health problems such as hookah use. Accurate planning and effective implementation can increase the effectiveness of health services and programs. Educational theories play an important role in designing effective interventions and changing behavior and lifestyle.

\section{Conflict of interest}

None.

\section{References}

1. Chaouachi KT. The narghile (hookah, shisha, goza) epidemic and the need for clearing up confusion and solving problems related with model building of social situations. The Scientific World Journal. 2007;7:16916.

2. Regulation WSGoTP. Advisory note: Waterpipe tobacco smoking: health effects, research needs andrecommended actions for regulators. 2015.

3. Mazloomy Mahmoodabad SS, Sadeghi R, Fallahzadeh H, Rezaeian M, Bidaki R, Khanjani N. Validity and Reliability of the Preventing Hookah Smoking (PHS) Questionnaire in Adolescents based on the Protection Motivation Theory. International Journal of Pediatrics. 2018:8327-37.

4. Sarrafzadegan N, Toghianifar N, Roohafza H, Siadat Z, Mohammadifard N, O'Loughlin J. Lifestyle-related determinants of hookah andcigarette smoking in Iranian adults. Journal of community health. 2010;35 (1):36-42.

5. Maziak W, Ward K, Eissenberg T. Factors related to frequency of narghile (waterpipe) use: the first insights on tobacco dependence in narghile users. Drug and alcohol dependence. 2004;76(1):101-6.

6. Maziak W, Ward K, Soweid RA, Eissenberg T. Tobacco smoking using a waterpipe: a re-emerging strain in a global epidemic. Tobacco control. 2004;13 (4):327-33.

7. Baheiraei A, Mirghafourvand $M$, Nedjat $S$, Mohammadi E, Charandabi SM-A. Prevalence of water pipe use and its correlates in Iranian women of reproductive age in Tehran: a population-based study. Medical Principles and Practice. 2012;21(4):340-4.

8. Akl EA, Gunukula SK, Aleem S, Obeid R, Jaoude PA, Honeine R, et al. Theprevalence of waterpipe tobacco smoking among the general and specific populations: a systematic review. BMC public health. 2011;11 (1):244.

9. Maziak W, Taleb ZB, Bahelah R, Islam F, Jaber R, Auf $R$, et al. The global epidemiology of waterpipe smoking. Tobacco control. 2015;24(Suppl 1):i3-i12.

10. Knishkowy B, Amitai Y. Water-pipe (narghile) smoking: an emerging health risk behavior. Pediatrics. 2005;116(1):e113-e9.

11. Arazi H, Hosseini R, Rahimzadeh M. Comparison of cigarette and hookah smoking betweenphysical education and non-physical education students. Journal of Jahrom University of Medical Sciences. 2013;11(3):57-63.

12. Martinasek MP, McDermott RJ, Martini L. Waterpipe (hookah) tobacco smoking among youth. Current problems in pediatric and adolescent health care. 2011;41(2):34-57.

13. Jahanpour F, Vahedparast H, Ravanipour M, Azodi P. The trend of hookah use among adolescents and youth: A qualitative study. J Qual Res Health Sci. 2015;3 (4):340-8.

14. Sadeghi R, Hashemi M, Khanjani N. The impactof educational intervention based on the health belief model on observing standard precautions among 
emergency center nurses in Sirjan, Iran. Health education research. 2018;33(4):327-35.

15. Syme SL, Smedley BD. Promoting health: Intervention strategiesfrom social and behavioral research: National Academies Press; 2000.

16. McKenzie JF, Neiger BL, Thackeray R. Planning, implementing, and evaluating health promotion programs: A primer: Pearson/Benjamin Cummings San Francisco; 2005.

17. Lopez A, Eissenberg T, Jaafar M, Afifi R. Now is the time to advocate for interventions designed specifically to prevent and control waterpipe tobacco smoking. Addictive behaviors. 2017;66:41-7.

18. Schulz KF, Altman DG, Moher D. CONSORT 2010 statement: updated guidelinesfor reporting parallel group randomised trials. BMC medicine. 2010;8 (1): 18 .

19. Islam F, Salloum RG, Nakkash $R$, Maziak W, Thrasher JF. Effectiveness of health warnings for waterpipe tobacco smoking among college students. International journal of public health. 2016;61(6):70915.

20. Leavens EL, Meier E, Tackett AP, Miller MB, Tahirkheli NN, Brett EI, et al. The impact of a brief cessation induction intervention for waterpipe tobacco smoking: A pilot randomized clinical trial. Addictive behaviors. 2018;78:94-100.

21. Ezati Rad R, Hassani L, Aghamolaei T, Ghanbarnejad A. Effect of Educational Intervention Based on Theory of Planned Behavior and Reduced Water Pipe smoking among Women above 15 (yrs.) in Bandar Abbas. Technical Journal of Engineering and Applied Sciences. 2015.

22. Momenabadi V, Kaveh MH, Hashemi SY. Effect of educational intervention on intention of University students' disuse of Hookah smoking: BASNEF model. Journal of Substance Use. 2018;23(3):262-7.

23. Anjum Q, Ahmed F, Ashfaq T. Knowledge, attitude and perception of water pipe smoking (Shisha) among adolescents aged 14-19 years. JPMA The Journal of the Pakistan Medical Association. 2008;58(6):312.

24. Lipkus IM, Eissenberg T, Schwartz-Bloom RD, Prokhorov AV, Levy J. Affecting perceptions of harm and addiction among college waterpipe tobacco smokers. Nicotine \& Tobacco Research. 2011;13 (7):599-610.

25. Fathi Y, Moeini B, Bazvand A, Barati M, Roshanaei G. The Effectiveness of Educational Program Based on Theory of Planned Behavior on Preventing and Decreasing Tobacco Smoking Among Post-secondary Students. J Educ Community Health. 2016;3(2):54-61.

26. Rajabalipour M. Application of social cognitive theory to prevention of waterpipe use in high school boys in Kerman city School of Health, Kerman University of Medical Sciences, Kerman, Iran; 2017.
27. Dawood AF, Obaid KB. Effectiveness of Health Education Program on High Schools Students' Perception of Hookah-Related to Health Problems in Baghdad City. Indian Journal of Public Health Research \& Development. 2018;9(10).

28. Setoudeh A, Tahmasebi R, Noroozi A. Effect of education by health volunteers on reducing water-pipe use among women in Bushehr: an application of health belief model. Journal of hayat. 2016;22(1):50-64.

29. Mojahed K, Navidian A. The effect of motivational interviewing on self-efficacy to quit hookah smoking in pregnant women. Journal of hayat. 2018;24(1):8496.

30. Jawad M, Abass J, Hariri A, Akl EA. Social media use for public health campaigning in a low resource setting: the case of waterpipe tobacco smoking. BioMed research international. 2015;2015.

31. Maziak W, Jawad M, Jawad S, Ward KD, Eissenberg $\mathrm{T}$, Asfar $\mathrm{T}$. Interventions for waterpipe smoking cessation. The Cochrane database of systematic reviews. 2015;7:CD005549.

32. Glanz K, Rimer BK, Viswanath K. Health behavior and health education: theory, research, and practice: John Wiley \& Sons; 2008.

33. Morton J, Song Y, Fouad H, El Awa F, El Naga RA, Zhao L, et al. Cross-country comparison of waterpipe use: nationally representative data from 13 low and middle-income countries from the Global Adult Tobacco Survey (GATS). Tobacco control. 2014;23 (5):419-27.

34. Dar-Odeh NS, Bakri FG, Al-Omiri MK, Al-Mashni HM, Eimar HA, Khraisat AS, et al. Narghile (water pipe) smoking among university students in Jordan: prevalence, pattern and beliefs. Harm reduction journal. 2010;7(1):10.

35. Tee GH, Hairi NN, Nordin F, Choo WY, Chan YY, Kaur G, et al. Systematic review on international practices in controlling waterpipe tobacco smoking. Asian Pac J Cancer Prev. 2015;16(9):3659-65.

36. Gardner MP, Adams A, Jeffreys M. Interventions to increase the uptake of mammography amongst low income women: a systematic review and metaanalysis. PLoS One. 2013;8(2):e55574.

37. Shams M, FayazbakhshA, Safari M. A Review of Studies Conducted on Efficacy of Health Educational Interventions to Correct Women's Behavior in Performing Breast Self-examination. Basic \& Clinical Cancer Research. 2014;6(2):2-9.

38. McLeroy KR, Norton BL, Kegler MC, Burdine JN, Sumaya CV. Community-based interventions. American Public Health Association; 2003.

39. Green LW, Kreuter MW. Health program planning: An educational and ecological approach: McGraw-Hill New York; 2005. 